\title{
Teachers' Perception of Values Education Implementation in School
}

\author{
Norliza Mohamad, Ahmad Johari Sihes, Normila Mohd Bohari, Siti Nur Hadis A Rahman
}

\begin{abstract}
Values education is an initiative to produce individuals with an active role in self-development, society and nation. The real aim of values education is to develop students with a strong personal identity and moral perspectives abilities. In the context of achieving values education, teachers' are the most influential person and play a pivotal role, and it is essential to understand teachers' perception related to values education. The present study established to examine extant studies on teachers' perception of values education implementation in the school. This research practised Systematic Literature Review methodology, led by PRISMA (Preferred Reporting Items for Systematic Review and Meta-Analyses), relevant articles sought from electronic databases, Web of Science and Scopus identified 14 linked studies after screening and quality assessment. This review paper analyses two significant themes of teachers' perception based on two research question, namely, (1) challenges and barriers and (2) teachers' support. From those two major themes, further produced five sub-themes. Findings indicate that teachers' reported obstacles in values education implementation such as teachers' competence, teachers' concern of students, and time constraints. Teachers felt supports that would improve their strengths to implement values education from collaboration support and teacher education. This suggestion of themes contributes to concerned parties to improve values education strategies that are in line with teachers' capacities, interests, and the challenges in the globalisation era.
\end{abstract}

Keywords: Systematic review, Teachers' perception, Values Education, Values

\section{INTRODUCTION}

Values and education are very interrelated and coalescing. Values are nourished by visions. Aristotle established that education developed an individual's mindset and abilities to perceive the highest existence, morality and virtue [1]. Education described as equipping individuals with knowledge, beliefs, ethical, and behaviours that will influence their lives [2]. In order to cultivate good citizens, values are reflected in the type of educational experience and always been a part of the school curriculum [3]. In other words, values education associated with many terms such as moral education, religious education, civic education, character education, citizenship education or homeland education [4]-[6]. Lickona (1991) mentioned that values education is a process to transfer values in education through curriculum

Revised Manuscript Received on October15, 2019

Norliza Mohamad*, Teacher, Tasek Utara National Secondary School. Email: norliza.mohamad1983@gmail.com

Ahmad Johari Sihes, Associate Professor, School of Education, Universiti Teknologi Malaysia. Email: p-joha@utm.my

Normila Mohd Bohari, Teacher, Temenggong Ibrahim Teachers' Training Institute. Email: milamiela@gmail.com

Siti Nur Hadis A Rahman, Doctorate Student, Islamic Civilisation Academy, Universiti Teknologi Malaysia. Email: asitinurhadis@yahoo.com and moral climate in school [7]. According to Halstead and Taylor (2000), values education refers to the development of attitudes and personal qualities [8]. Aspin (2007) stated that values education is an introduction of values to the young generation in order to behave in a community with values applied [9]. Values education present in the explicit and implicit curriculum[6], [10]. The concept of values education may define differently in different countries based on their social, cultural, economic, socio-historical and socio-political reasons. However, all country may have common sharing in terms of goals in values education. Many developed and developing countries focus on values education in their national education system due to the demand of the society to develop great future citizens for sustainable in the economy, politic, social, science and technology. For example, the initiatives had made by the United States of America government to introduce the iCivics programs into their national curriculum [11]. This effort is to provide civic engagement to their students in an interactive way and for the long term goal to create active citizens for a better future life. Same goes to other Western countries, European and Asia like Australia, England, Turkey, India, Singapore and many more country had efforts to strength values education in their national education curriculum for a sustainable future. Other reasons to implement values education is to develop active citizenship among youth especially students such as prevent them from a moral crisis, create awareness towards nature and community and improve their attitudes to face challenges in this modern epoch [12]. There is a responsibility for educating future citizens as a person able to think and to act with moral abilities. In countries like China, the socialization of the young people seen as a vital part of the process of building a new order in society [13]. A study by Matakupan, Putrawan and Neolaka (2019) showed that students' citizenship behaviour need towards environment sustainable [14]. We realized that values education across a variety of disciplines. Because of that, the importance of values education implementation in all aspects and phases cannot be denied.

For successful of values education, involves teachers' efforts to deal with community needs and teachers often conceptualised as primary agents and sources of values for the young generations. According to Arthur (2011), teachers require to view themselves as moral agents and manifest the kind of positive representative moral behaviour that the nation required to see in students as their future civilian [15].

Published By:

Blue Eyes Intelligence Engineering

DOI:10.35940/ijrte.C1220.1083S219 
Teachers play a vital dimension of values education besides other stakeholders due to they are the most intimate group to students, albeit the students first gain their values from their parents and family [5]. Lovat and Hawkes (2013) also added that teachers' role is meaningful in affecting students' formation [5]. Teachers' have a more significant influence in curriculum practice, intellectual stimulus, and teachers influence are a dominant factor in the actual implementation of values education. According to Carr (1998), values education belongs to the soul of the role of teachers [16]. If teachers are teaching values just the same with other school subjects, this can be affected by a failure of values education implementation. Education is about the development of persons and every part seen teachers have full responsibility to educate the young generation with values. As Lovat, Clement, Dally and Toomey (2010) stated, holistic development of students as a piece of holistic pedagogy, and this is related to teacher effective performance [17].

Naturally, the values education lead along with the investigation of teachers' part in an individual's development and teachers' ability in the implementation. Although teachers seen as values transmitter and have abilities to cause desirable values learning in students, most important is attending carefully to teachers perceptions of values education implementation. Teachers may be less affected than the other person in other professions, but teachers work with a human being, the innovations in the system education and the more general process of social transformation make the teaching profession very challenges. Teachers are encouraged to create supportive environments and great emphasis relationship in teaching values due to high demand from society [18].

Teachers have much advice on how to tackle values in teaching practice; however, lack of review studies exist determining the prior held perceptions and perspectives of these teachers towards values education. Key stakeholders need to understand the challenges and barriers faced by teachers to implement values education. Other than that, all stakeholders need to identify teachers support to effectively implement values education for their students. For empower teachers abilities to teach values education, it is very imperative to look deeper into their perceptions, views and perspectives towards values education. According to $\mathrm{Li}$, Kennedy and Tan (2016), teachers' perception might influence teacher' attitudes, behaviour and methods to the practice of civic education in schools [13]. Teachers' perception is the mental process by the individual teachers to acquire knowledge from the surrounding environments, interprets the information, classifies it into their mental framework and related to their teaching [19]. Teachers' perception also associated with teachers' attitudes and teachers' behaviour towards values education implementation.

A systematic review is an explicit method to examine and analyse data in critically based on specific criteria. For this study, the authors' using PRISMA four-phase of a flow diagram to run a systematic review process. Despite abundance studies on values education, attempts to review these studies are still requiring. This review article aims to fill the chasm in examine and identifies the values education perception among school teachers. Before this study, review articles on values education is quite general and not present detail analysis on how the review procedures implemented, so it is quite tricky and challenging for future researchers to reflect on the study. Furthermore, this review study is crucial for all stakeholders due to teachers' is expected to play a desirable role for successful of values education implementation. As this systematic review study focuses on analysing articles with empirical data, we will not present a critical theoretical analysis that can be discovered in the literature elsewhere.

\section{METHODOLOGY}

This systematic review utilized the method called PRISMA (Preferred Reporting Items for Systematic Review and Meta-Analyses) to retrieve articles related to the teachers' perception towards values education implementation in school from databases resources, namely, Web of Science and Scopus. PRISMA as guidelines used to manage the systematic review process based on a four-phase flow diagram, through identify phase, screening, qualification (eligibility), extract the data and analyse phase.

\section{A. PRISMA}

PRISMA directed this systematic review and consists of four-phase flow-diagram [20]. PRISMA consistently to run the systematic review process in the context of medical science and health disciplines. However, in terms of retrieve and analysis articles with quality assessment, the PRISMA quite general of other studies included Social Sciences. The advantages of using PRISMA allows a rigorous search of terms and related to teachers' perception of values education in school. PRISMA supports researchers and reviewers to improve their review study in performing, presenting or reporting.

\section{B. Resources}

Journal databases were electronic and concerned areas of education, social sciences and humanities. Two primary databases searched are Web of Science (WoS) and Scopus. WoS is the first database used in this review and produced by Thomson Reuters (ISI). Wos consists of more than 33,000 credible journals with the inclusion of 256 fields of study. Every publication indexed within WoS has passed through a rigorous evaluation process. Most of WoS journals written in English and have a high impact [21].

The following database practised in this review is Scopus and it introduced by Elsevier Science in 2004. Scopus is the most extensive searchable citation and abstract with more 22,000 titles of journals from more than 5000 global publishers. There is a variety of field code function in the Scopus database. One of the critical field code function is TITLE-ABS-KEY, and it is referring to title, abstract and keywords. This code function beneficial to create more article related to the author's study. Scopus comprises journals from high-level discipline includes life science, health science, environmental science, physical science and social science. Scopus reviewed every year of journals in their lists to ensure the quality of publishing articles well maintained. 


\section{Eligibility and exclusion criteria}

In order to select studies for the systematic review, a few eligibility and exclusion criteria determined. For the first criteria, only journal articles with empirical data and published in the scholarly journal are accepted. This review excluded all the literature type published as review articles, articles in conference proceedings, book and chapter in a book. Following criteria, the searching efforts focus on articles published in English. The third criterion, a timeline of 10 years of journal articles, is chosen between 2009 and 2019. Finally, in line with the objective of this review, to examine teachers' perception of values education in school, articles focus on educators in universities or higher education are excluded (see Table 1). This study also includes pre-service teachers' perception of values education.

Table- I: The eligibility and exclusion criteria.

\begin{tabular}{|l|l|l|}
\hline Category & \multicolumn{1}{|c|}{ Qualification } & \multicolumn{1}{c|}{ Exclusion } \\
\hline $\begin{array}{l}\text { Literature } \\
\text { category }\end{array}$ & $\begin{array}{l}\text { Journal (studies } \\
\text { with empirical data) }\end{array}$ & $\begin{array}{l}\text { Journal (articles } \\
\text { without empirical } \\
\text { data) books }\end{array}$ \\
\hline Language & English & Other than English \\
\hline Timeline & From 2009 to 2019 & $<2009$ \\
\hline
\end{tabular}

\section{Systematic review process}

A review process begins in July 2019 and four phases implicated in the systematic review process. The first stage identified the keywords practised in the search process. Based on preceding studies and glossary, keywords linked and parallel to values education, teachers' perception and implementation used (see Table 2). At this level, 53 articles retrieve using database selected, Web of Science (5 articles) and Scopus (48 articles). After the precise screening, two replicated articles excluded.

Table-II: The search string practised for the systematic review process

\begin{tabular}{|c|c|}
\hline Databases used & Keywords applied \\
\hline Web of Science & $\begin{array}{l}\text { TS=(("value* education" OR "civic } \\
\text { education" OR "moral education" OR } \\
\text { "character education" OR "citizenship") } \\
\text { AND ("teacher*" OR "educator") AND } \\
\text { ("perception" OR "view" OR "opinion" } \\
\text { OR "perspective" OR "perspectives") } \\
\text { AND ("implementation" } \\
\text { "application") AND ("school" OR } \\
\text { "classroom")) }\end{array}$ \\
\hline Scopus & $\begin{array}{l}\text { TITLE-ABS-KEY (("value* education" } \\
\text { OR "civic education" OR "moral } \\
\text { education" OR "character education" OR } \\
\text { "citizenship") AND ("teacher*" OR } \\
\text { "educator") AND ("perception" OR } \\
\text { "view" OR "opinion" OR "perspective" } \\
\text { OR "perspectives") } \\
\text { ("implementation" OR "application") } \\
\text { AND ("school" OR "classroom")) }\end{array}$ \\
\hline
\end{tabular}

The screening was the second phase applied in this review. At this level, a total of 51 studies qualified to review. A total of 23 studies excluded due not to fulfil the inclusion criteria. Twenty-eight full articles accessed for eligibility at the third phase. These twenty-eight full articles following attentive checking and assessment, a total of 14 articles eliminated due to some studies did not concentrate on teachers' perception of values education and did not apply in school context. The final phase of this review process ended in a result of 14 studies accepted for in-depth analysis (see Fig. 1).

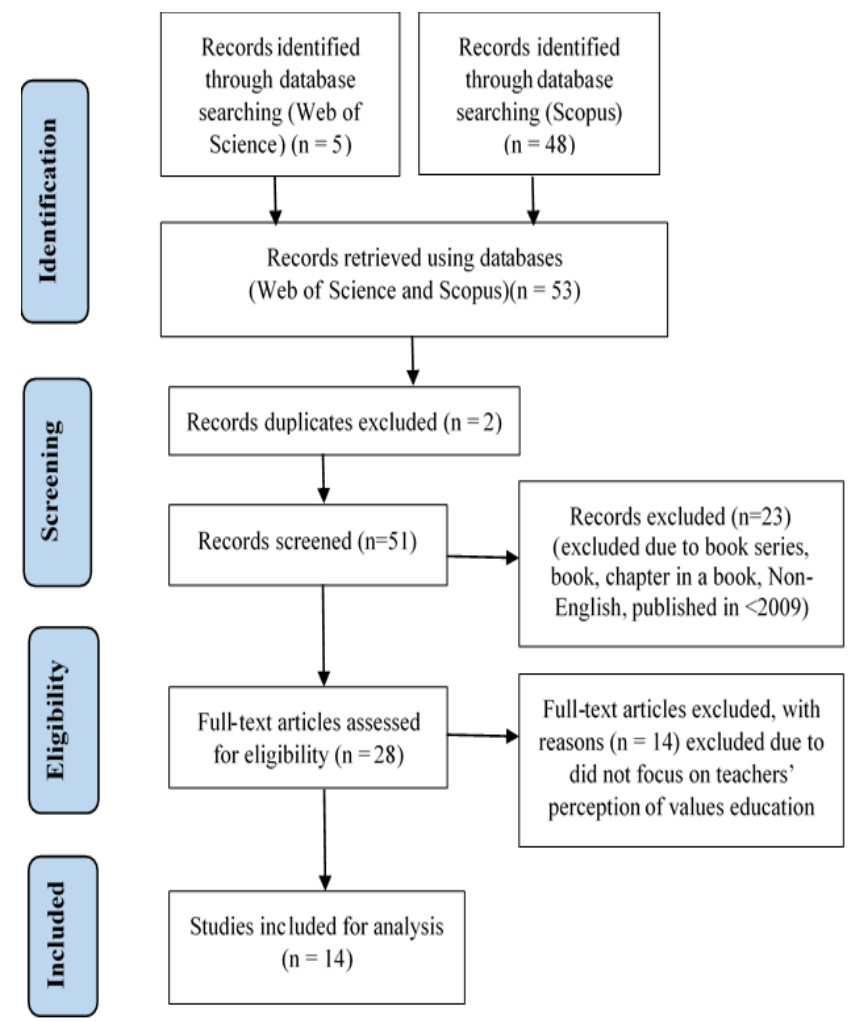

Fig. 1.

The flow chart shows the process of the studies culled down from identification phase to the final resulted studies. (Adapted from Moher, Liberati, Teztlaff and Altman, 2009)

\section{E. Data extraction and analysis efforts}

The 14 studies evaluated and analysis based on the objective and the formed research question. The data extracted by comprehensive reading the abstracts and full articles and then applied content analysis to full articles to recognize themes and sub-themes related to teachers' perception towards values education implementation in the school.

\section{RESULTS AND FINDINGS}

The systematic review efforts produced two central themes linked to teachers' perception of values education implementation in school. The two main themes are challenges and teachers' support. Three sub-themes emerged from the challenges theme, namely, teachers' competence, teachers' concern of students and time constraints. Two sub-themes developed from the second theme, specifically, collaboration and teacher education (Table 3 ). 
Based on the country, a total of six studies focused on Asian teachers' perception of values education implementation [13], [18], [22]-[25].

Five studies focused on European teachers' perception [26]-[30], one study concentrated on teachers' perception in Australia country, one study conducted in South Africa and one study focused on teachers' perception of values education in Cyprus.

Regarding years published, the period of 10 years chosen between 2009 and 2019. Two articles published in 2018, three studies publication issued in 2017 , three studies issued in 2016, two studies issued in 2015, one study issued in 2012, one study issued in 2010, and two studies issued in 2009.

Concerning the methodology applied in the selected articles, two studies used the quantitative method, eight studies employed the qualitative method, and four studies applied a mixed methods (quantitative and qualitative) approach.

\section{i. Teachers' competence challenge}

A total of 12 out of 14 studies concentrated on teachers' competency challenge in values education implementation. Competence is an integrated combination of knowledge, skills, personality and attitudes to recognize a particular activity in a specific context. From the review, three main competencies cited by teachers' as inhibiting factors to values education, namely, knowledge, skills and attitudes. Teachers are keen to implement values education, but they faced a lack of knowledge [22], [23], [26]. Values education requires teachers to understand the notion of values, but most of them do not understand clearly the concept, terminology of values and shared values that related to their teaching subject [27], [30]. Some of the teachers clarifying values through their personal experience and make less discussion of values with their students [13], [24]. Teachers' felt they wanted clarity to implement values education in line with educational aims. According to Li, Kennedy and Tan (2016) and Li and Tan (2017) studies, teachers might inaccurately or unintentionally misinterpret the implementation of values education as politic or government agenda [13], [24].

Table- III: The findings of 14 articles.

\begin{tabular}{|c|c|c|c|c|c|c|}
\hline \multirow[t]{2}{*}{ Author(s)/countries } & \multirow{2}{*}{$\begin{array}{c}\text { Study } \\
\text { desig } \\
\text { n }\end{array}$} & \multicolumn{3}{|c|}{ Theme- Challenges and barriers } & \multicolumn{2}{|c|}{ Theme- Teachers support } \\
\hline & & $\begin{array}{c}\text { Teachers } \\
\text { competenc } \\
\mathbf{e}\end{array}$ & $\begin{array}{l}\text { Students } \\
\text { concerns }\end{array}$ & $\begin{array}{c}\text { Time } \\
\text { constraints }\end{array}$ & $\begin{array}{l}\text { Collaboratio } \\
\text { n support }\end{array}$ & $\begin{array}{c}\text { Teacher } \\
\text { Education }\end{array}$ \\
\hline Arifin (2017)-Indonesia & QL & I & & I & & \\
\hline Devjak et al. (2009)-Slovenia & MM & l & / & I & / & l \\
\hline Koh et.al (2016)-Singapore & QL & I & / & / & / & I \\
\hline Bacia and Ittel (2017)-Germany & MM & / & / & / & / & / \\
\hline Peterson and Knowles (2009)-UK & QN & l & & & & / \\
\hline Li, Kennedy and Tan (2016)-China & QL & l & & & / & / \\
\hline Li and Tan (2017)-China & QL & I & & & I & I \\
\hline $\begin{array}{l}\text { Long and McPolin (2010)- } \\
\text { N.Ireland }\end{array}$ & QN & I & I & I & & I \\
\hline Ozdilekler et al. (2018)-Cyprus & QL & l & & & / & / \\
\hline $\begin{array}{l}\text { Mphalala and Mpofu } \\
\text { (2018)-S.Africa }\end{array}$ & QL & / & & & / & \\
\hline Chang and Chou (2015)-Taiwan & MM & I & & & & \\
\hline $\begin{array}{l}\text { Peterson and Bentley } \\
\text { (2016)-Australia }\end{array}$ & QL & l & l & l & & \\
\hline McNaughton (2012)-UK & $\mathrm{QL}$ & & I & & & 1 \\
\hline Wong et al. (2015)-Hong Kong & $\mathrm{MM}$ & & & & I & I \\
\hline & & 12 & 6 & 6 & 8 & 10 \\
\hline
\end{tabular}

\section{A. What do teachers' recognize as challenges to implement values education in schools?}

The area teachers recognized as challenges related to values education implementation categorized into three sub-themes: teachers' competency, teachers' concern of students, and time constraints.
Skills competency critical for teachers to deliver values education. From this review, teachers expressed concerns related to specific skills for teaching values to their students. Teachers felt they are not good enough to apply teaching skills in terms of values education. Teachers faced a challenge to define and to teach values in terms of clarifying or simplifying the concept of 
values to their students, especially in a real situation [23]. Teachers are struggling to determine appropriate strategies for teaching values education due to less specific guidelines from teacher education [28]. Arifin (2017) study found that teachers not capable of integrating values into their teaching lessons; for example, they isolated teaching core-subject and teaching values [22]. Teacher also fewer skills of understanding students level of developments and they used any method without thinking students cognitive abilities and social growth [28]. Ozdilekler (2018) study reported that teachers' are not capable of using technology as an interactive medium for teaching values, albeit they are excellence in find available right resources related to values education [31]. Teachers did not plan to incorporate values into teaching lesson instead of teaching values by spontaneously. Chang and Chou (2015) studies found that teachers faced difficulty with explaining to their students about good virtue during the e-character education (CE) lesson [25]. On the contrary, Maphalala and Mpofu (2018) studies reveal that teachers used diverse strategies to teach values such as case studies, role-plays and discussion [32]. Teachers believe a variety of strategies will create a positive environment and active participation among students towards values learning [32].

For attitudes competency, teachers believe they have the authority and play a vital part in teaching values education to students [31]. Teachers affirmed that they have efforts to instil values by showing an ethical manner and become a role model to their students through their action and present attitudes [27]. Teachers also realized that teaching values would have a significant impact on students' behaviour and academic achievements. A study reported by Li, Kennedy and Tan (2016), Chinese teachers believe that they have high civic awareness, $74 \%$ teachers mentioned patriotism is important, and $80.2 \%$ of teachers felt angry with negatives statement-making by other people to their country [13]. Studies by Peterson and Knowles (2009) have shown that students-teachers committed to the development of active citizenship [30]. However, Arifin (2017) study reveals that in-service teacher convey teaching values to students as the final task list due to delivering knowledge in the main subject is prioritize task and more important than promoting values. Teachers also claimed that they do not have the confidence to teach values due to their mindset that teachers need to build their character first before instilling values to students [22]. Wong (2015) study reveal that some teachers perceived negative attitudes on implementation of Moral and National Education (MNE) due to their judgements of MNE as a patriotic agenda [18]. They are also labelling the MNE as 'political brainwashing' from the government that might give a negative effect on students and school environments [18]. Teachers' attitudes competency has a significant association with teachers' orientation in values teaching.

\section{ii. Teachers concern of students challenge}

Six studies focused on the teachers' concerns of their students in the implementation of values education. Teachers by nature should be a concern of students, but in terms of values education teachers worried too much of students' readiness and these perceptions seen not well. McNaughton (2012) study found that teachers were concerned regarding students' thinking and the level of their understanding in terms of activities and discussion related to values education. For example, teachers' felt worried about students level of thinking in controversial issues and sometimes that issues become debated among students' [29]. Long (2010) also found that teachers expressed concerns with students thinking, applying of values education in another context, and how teachers will evaluate this thinking [28]. Koh (2017) study also reported that teachers faced challenges in explaining the meaning of values in a simple way to their students. Teachers reveal that students have responded to the meaning in different understanding [23]. Teachers believe that students not ready for values education due to students still struggling with exam-oriented and focus more on academic achievements rather than values. Besides, students' not take precedence of values education due to many schools locate the subject as the last period of the day [26]. Teachers stated that students do not merely respond to the content of values. Teachers perceived that some students do not receive values taught from their parents [33]. Bacia and Ittel (2017) studies reported that teachers do not want to encourage and do not want to argue with their students in terms of values due to their parents are difficult to engage [27]. Teachers also reported a lack of teaching tools into teaching values for students to feel more motivated and interested in values education make them put this task in the last place. Teachers also reveal that to develop students' empathy is quite robust in terms of values education. Teachers believed that this situation related to students experience and family background. McNaughton (2012) affirmed that teachers must admit students' sensitivity and keep in mind that students also have a right and beliefs [29].

\section{iii. Time constraints challenge}

From this review, six studies mentioned time constraints as a challenge of teachers' for teachers in values education implementation. Teachers perceive a lack of planning due to their teaching workload [28], [33]. Teachers stated that they, not enough time to manage with values teaching initiatives due to the increased workload in school [26], [28]. For example, teachers stated that they do not have time to plan and familiarise with assessment task, thinking skills activities, teachers capabilities in personal and civic education teaching [28]. Teachers mentioned with little allocation time of values education implementation, they just merely teaching values and select any materials without thinking the impact of their lesson plan to students' achievements. Devjak (2010) reveal that citizenship and Homeland education subject is a place for only one hour per week, and it is not adequate [26]. Bacia and Ittel (2017) found that teachers faced a challenge of time to make teacher-parent cooperation due to teachers' workload [27]. A study from Arifin (2017) reveals that teachers felt exhausted in terms of values education evaluation tasks [22] Koh (2017) study show that teachers faced challenging to spend time between preparing skills of their athletes and teaching values in the implementation of values training among sports students [23].

\section{Published By: \\ Blue Eyes Intelligence Engineering}

DOI:10.35940/ijrte.C1220.1083S219 
B. What supports do teachers feel would improve their strength to implement values education?

Two areas found in this review that addressed teachers' need for support in implementation values education. They were in the areas of collaboration support and teacher education support.

\section{i. Collaboration support}

A total of nine studies out of 14 studies reported that teachers always need collaboration support from other stakeholders in terms of values education implementation. Teachers believe that a culture of collaboration would increase the effectiveness of values education [31]. Teachers mentioned the significance of collaborating with other teachers, administrators, parents, community and government in order to not only create an atmosphere that enhances for values education implementation but also to produce $\mathrm{s}$ active team approach towards values education. Devjak (2009) study reveals that teachers felt dissatisfied with interpersonal collaboration with external colleagues and professionals in terms of citizenship and homeland education [26]. Bacia and Ittel (2017) also found that communication between teachers and the headmaster is weak in terms of citizenship and character education implementation [27]. Koh, Camire, Regina and Soon (2016) study found that physical education teachers agreed that schools must give moral support and upheld to raise awareness towards the implementation of values among teachers due to some negatives perceptions made by other subject teachers [23]. Other study reveals that teachers do not feel safe and refuse to teach civic education due to pressure and negative perception from parents and media in terms of creating future citizen for the nation [18]. In line with this, teachers want policymakers to have structure planning to overcome an issue faced by teachers and society. Teachers believe that collaboration was the key to the success of values education implementation, and it will not be adequate to rely on one party to implement it [13], [18], [22], [24], [26], [27], [31], [32]. Teachers also need support from other stakeholders to accomplish their roles as values educators.

\section{ii. Teacher education}

A total of 10 studies reported that teachers' needs teacher education to support their roles in values education implementation. Devjak (2010) study found that teachers affirmed that additional education and training should provide resources and pedagogical skills for values teaching. Long (2010) affirmed that teachers training must assist teachers with personal growth and reflective practice in teaching to ensure they have capacities and a holistic approach towards values education [28]. Teacher institution training needs to prioritize teacher programs with educational and psychological theories of child developments to enhance teachers' knowledge of students abilities and students level development [28]. Maphalala and Mpofu (2018) stated that the school management team must consider teachers professional development before have appointed them to teach values in the curriculum [32]. From this review, many researchers indicated that it would be imperative to provide values in education instruction and training in teacher training institute or in-service teacher education programs. Li and Tan (2017) and Wong et al. (2015) reported that teachers need professional development to increase their awareness and create a positive mindset due to some teachers have a negative perception and personal judgement of values education implementation [18], [24]. McNaughton (2016) study reveals that teachers need teacher education programs to create critical reflection practice towards values education implementation [29]. Long (2010) study stated that teachers expressed interests to participate in professional development programs that relate to personal and civic education. Teachers motivated to gain more knowledge from professional development programs as they received previously while in pre-service teacher education. Through initial teacher education programs, the undergraduate teacher would increase their opportunities in practice skills of values education implementation [28].

\section{DISCUSSION}

The main objectives of the present this systematic review was to examine studies that have explored teachers' perception of values education implementation in the school. Two research question developed to achieve this review objectively. From the research question, there are several emerging sub-themes related to the teacher' views as their challenges in terms of values education implementation, namely teachers' competency, teachers concern of students and time constraints. This review reveals that significant challenge faced by teachers is teacher competency. Teachers competency should take into account due to the review resulted in 12 studies related to teachers' knowledge, skills and attitudes as challenges in values education implementation. Teachers must have the ability to set appropriate subject knowledge relating to values education and the aims of the national curriculum [6]. For attitudes competency to teach values education, teachers realized they possess values authority. However, from this review, teachers do not appreciate that they are elected representatives of the community includes parents for the successful formation of students' values. Teachers must realize whether they intend it or not, teachers are teaching more than subject matter. Then it becomes imperative to have a critical reflection of the values related to their teaching subject. The importance of having competent teachers in values education cannot be underestimated; failure to make the right decision about instil values to students will have fateful consequences. Devjak, Blazic and Devjak (2009) insist that the teacher needs to organized, systematic in their works and must have a responsibility in choosing or planning lesson of values education [26]. From this review, many researchers agreed that teachers must have specific competency and positive attitudes towards values education.

In terms of teachers concerns of students, most studies discussed students' thinking ability and students receptivity as teachers challenge in the implementation of values education. Teachers must shift their judgement and make some efforts to

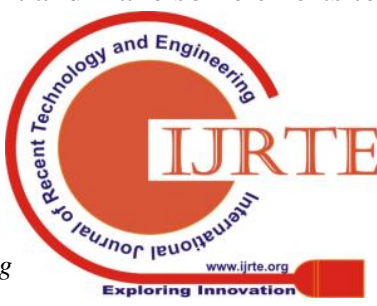


find suitable strategies for values education implementation.

Teachers must respects each student as a unique human being and has potential. Teachers encouraged to make an establishment of developing trusts with students' abilities. Teachers need to become comfortable to allow their students to take parts into values discussion and need to see the students more in terms of values transfers. The time aspect is very significant in values education. Most of the studies reveal that teachers faced difficult to plan of values education teaching because of limited time. More time demands to be allocated to teachers for practice, preparing and evaluating in values education. Provisions need to be made to place values education in the school time table.

Values education was carried out in a teacher-centred approach. In order to supports teachers' and values education implementation, necessary provisions need to be taken in teacher training. Teacher education programs should focus on teacher competency, especially contextual knowledge courses, instruction skills and ethics in terms of values education implementation [28]-[30]. The instructional strategies associated with values education must be explicitly taught to teachers. Teachers should be encouraged to participate in teachers' professional development programs such as a seminar or workshop related to values education. The seminar or workshop provides must create opportunities for teachers to think, reflect and talk about their teaching practice and experiences of values education. This seminar would not be professional in nature but focuses on practical and discussion of values education practice among teachers.

Active collaboration helpful in terms of the success of values education due to teachers, schools, parents, policymakers or government are sharing common goals in values education [28]. School leaders and parents should encourage teachers towards values education, and teachers should solicit other advice in complicated situations in terms of values education. According to Durdukoca (2019), professional development related to values education should explicitly develops for teachers, and active collaboration supports such as from media can be involved to enhance an appreciation for values education [34]. If teachers are essential to engage in integrating and implementing values education, they must be prepared to apply in teacher education programs or professional development programs. Conceptually all themes and sub-themes in this review are linked. Overall, this systematic review provided evidence to suggest teachers faced challenges in terms of values education implementation, and they need strong supports in their professional learning and practice in order to successfully achievement of values education aims.

\section{Recommendation for future research}

From the review, it is essential to explore the reasons underlying teachers' competency in three domain (knowledge, skills and attitudes) towards values education. According to Carr (1998), professional teachers values are best appreciated based on three aspects related to teachers competency namely, 'intellectual virtues', 'procedural virtues' and 'moral virtues' [16]. More research needs to be done to understand the teachers' beliefs to integrate values education into their teaching due to teachers' beliefs have reflected on teachers attitudes, and it is very related to teachers' perceptions [18], [35]. More quantitative studies are needed as it offers more respondents to generalize the results. Other than that, mixed-methods studies suggest in order to offer in-depth analysis, get details explanation from participants, including experts, and combining the results with statistical data from quantitative analysis. Finally, further research is necessary to refine and validate the themes and subthemes that emerged from this review study from experts' context.

\section{CONCLUSION}

While many researchers have debated of values education, a few have described the perceptions of teachers in values education through review analysis. The 14 findings from this review suggested that there are two themes of teachers' perception based on research question developed. Five sub-themes emerged from this review on values education implementation need to be seen as crucial issues to support teachers for values education initiatives. Articles selected for this systematic review found across multiple studies can be fundamental view and approach for scholars, policymakers, and curriculum development division or teacher education to enhance strategies and teachers development programs of values education.

\section{ACKNOWLEDGMENT}

We are grateful to Universiti Teknologi Malaysia for providing the electronic databases and Ministry of Education Malaysia for sponsoring the scholarship that enables this study to be carried out.

\section{REFERENCES}

1. A. Silverstein and I. Trombetti, 'Aristotle's account of mora development', J. Theor. Philos. Psychol, vol. 33, no. 4, pp. 233-252, 2013.

2. A. Katılmış, 'Values education as perceived by social studies teachers in objective and practice dimensions', Kuram ve Uygulamada Egit. Bilim., vol. 17, no. 4, pp. 1231-1254, 2017.

3. J. M. Halstead and M. J. Taylor, Eds., Values and Values Education in Schools. London: The Falmer Press, 1996.

4. M. W. Berkowitz, 'What works in values education', Int. J. Educ. Res., vol. 50, no. 3, pp. 153-158, 2011.

5. T. Lovat and N. Hawkes, 'Values Education: a Pedagogical Imperative for Student Wellbeing', Educ. Res. Int. Educ. Res. Int Educ. Res. Int. Educ. Res. Int. ISSN-L, vol. 2, no. 2, pp. 2307-3713, 2013.

6. A. G. Mergler and R. Spooner-Lane, 'What Pre-service Teachers need to know to be Effective at Values-based Education', Aust. J. Teach. Educ., vol. 37, no. 8, 2013.

7. T. Lickona, 'Educating for Character: How Our Schools Can Teach', pp. 494-496, 1991.

8. J. M. Halstead and M. J. Taylor, 'Learning and Teaching about Values: A review of recent research', Cambridge J. Educ., vol. 30 no. 2, pp. 169-202, 2000.

9. David N. Aspin and J. D. Chapman, Eds., Values Education and Lifelong Learning, Volume 10. Netherlands: Springer, 2007.

10. M. Etherington, 'Values Education: Why the Teaching of Values in Schools is Necessary, But Not Sufficient', J. Res. Christ. Educ., vol. 22, no. 2, pp. 189-210, 2013 .

11. B. Blevins, K. LeCompte, and S. Wells, 'Citizenship education goes digital', J. Soc. Stud. Res., vol. 38, no. 1, pp. 33-44, 2014. 
12. C. Ferreira and S. Schulze, 'Teachers' experience of the implementation of values in education in schools: "mind the gap", South African J. Educ., vol. 34, no. 1, pp. 1-13, 2014.

13. H. Li, K. J. Kennedy, and C. B. Tan, 'Chinese teachers' perceptions of the "good citizen": Implications for implementing China's civic education curriculum', Citizsh. Teach. Learn., vol. 11, no. 2, pp. 139-156, 2016

14. S. J. Matakupan, I. M. Putrawan, and A. Neolaka, 'The effect of personal commitment and personal investment, intention to act on students' citizenship behaviour (A 2016 causal study from students of east Java)', Int. J. Recent Technol. Eng., vol. 7, no. 6, pp. 803-807, 2019.

15. J. Arthur, 'Personal character and tomorrow's citizens: Student expectations of their teachers', Int. J. Educ. Res., vol. 50, no. 3, pp. 184-189, 2011.

16. D. Carr and J. Landon, 'Teachers and schools as agencies of values education: Reflections on teachers' perceptions: Part One: The role of the teacher', J. Beliefs Values, vol. 19, no. 2, pp. 165-176, 1998

17. T. Lovat, N. Clement, K. Dally, and R. Toomey, 'Values education as holistic development for all sectors: Researching for effective pedagogy', Oxford Rev. Educ., vol. 36, no. 6, pp. 713-729, 2010.

18. K. L. Wong, C. K. J. Lee, K. J. Kennedy, and J. K.-S. Chan, 'Hong Kong teachers' receptivity towards civic education', Citizsh. Teach. Learn., vol. 10, no. 3, pp. 271-292, 2015.

19. G. Yavuz Konokman, T. Yanpar Yelken, K. Karasolak, and E. Cesur, 'Teachers' Perception: Competent or Not in Curriculum Development.', Malaysian Online J. Educ. Sci., vol. 5, no. 4, pp. 56-73, 2017.

20. D. Moher, A. Liberati, J. Tetzlaff, and D. G. Altman, 'Preferred reporting items for systematic reviews and meta-analyses: the PRISMA statement', J. Clin. Epidemiol., 2009.

21. A. Joshi, 'Comparison Between Scopus; ISI Web of Science', $J$. Glob. Values ISSN, vol. VII, no. 1, pp. 976-9447, 2016.

22. M. A. Arifin, 'The Teaching Methodology and Assessment of Character Education in Indonesian English Curriculum : Teacher 's Perceptions The Asian EFL Journal Second Language Acquisition - Academic Research TESOL Indonesia International Conference Edition Volume 10 Seni', no. March, 2017.

23. K. T. Koh, M. Camiré, S. H. Lim Regina, and W. S. Soon, 'Implementation of a values training program in physical education and sport: a follow-up study', Phys. Educ. Sport Pedagog., vol. 22, no. 2, pp. 197-211, 2017.

24. H. Li and C. Tan, 'Chinese teachers' perceptions of the "good citizen": A personally-responsible citizen', J. Moral Educ., vol. 46, no. 1 , pp. 34-45, 2017.

25. C. M. Chang and C. Chou, 'An exploratory study of young students' core virtues of e-character education: The Taiwanese teachers' perspective', J. Moral Educ., vol. 44, no. 4, pp. 516-530, 2015.

26. T. Devjak, M. Blažič, and S. Devjak, 'Teachers' and learners' perspectives on factors influencing the implementation of the citizenship and Homeland education and Ethics subject in primary school', Croat. J. Educ., vol. 11, no. 2, pp. 7-26, 2009.

27. E. Bacia and A. Ittel, 'Education to thrive in a heterogeneous and democratic society-a task for citizenship and character education? Results of case studies in three Berlin schools', J. Soc. Sci. Educ., vol. 16, no. 3, pp. 39-50, 2017.

28. L. Long and P. McPolin, 'Personal and civic education in the Northern Ireland primary curriculum: Teachers' perspectives', Pastor. Care Educ., vol. 28, no. 2, pp. 109-129, 2010.

29. M. J. McNaughton, 'Implementing Education for Sustainable Development in schools: Learning from teachers' reflections', Environ. Educ. Res., vol. 18, no. 6, pp. 765-782, 2012.

30. A. Peterson and C. Knowles, 'Active citizenship: A preliminary study into student teacher understandings', Educ. Res., vol. 51, no. 1, pp. 39-59, 2009.

31. M. A. Özdilekler, F. Altınay, Z. Altınay, and G. Dağlı, 'An evaluation of class-teachers' roles in transferring values', Qual. Quant., vol. 52, pp. 1043-1058, 2018.

32. M. C. Maphalala and N. Mpofu, 'Embedding values in the South African curriculum: By design or default?', South African J. Educ., vol. 38 , no. 3, pp. 1-11, 2018.

33. A. Peterson and B. Bentley, 'Education for citizenship in South Australian public schools: a pilot study of senior leader and teacher perceptions', Curric. J., vol. 28, no. 1, pp. 105-122, 2016.

34. Ş. Firat Durdukoca, 'Identifying the Attitudes and Views of Social
Sciences Teachers toward Values Education in Turkey', World $J$. Educ., vol. 9, no. 1, p. 103, 2019.

35. M. Chowdhury, 'Emphasizing Morals, Values, Ethics, and Character Education in Science Education and Science Teaching.', Malaysian Online J. Educ. Sci., vol. 4, no. 2, pp. 1-16, 2016.

\section{AUTHORS PROFILE}

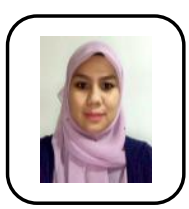

Norliza Mohamad. She is a preuniversity teacher at Tasek Utara National Secondary School, Johor Bahru, Malaysia. She is pursuing a doctoral studies at School of Education, Faculty of Social Sciences and Humanities, Universiti Teknologi Malaysia. Her $\mathrm{PhD}$ program is Curriculum and Instruction.

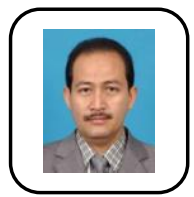

Ahmad Johari Sihes. He is currently Associate Professor at School of Education and Assistant Dean at Faculty of Social Sciences and Humanities, Universiti Teknologi Malaysia. His research areas and interests are Curriculum Development, Curriculum Evaluation, Higher Education, Instruction and Teaching.

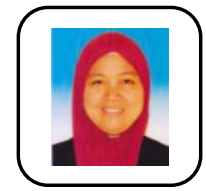

Normila Mohd Bohari.She is a teacher at Temenggong Ibrahim Teachers' Training Institute, Malaysia. She is pursuing a doctoral degree at School of Education, Faculty of Social Sciences and Humanities, Universiti Teknologi Malaysia. Her PhD program is Technical and Vocational Education (TVET)

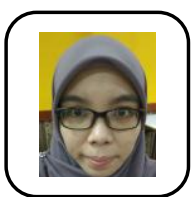

Siti Nur Hadis A Rahman.She is currently a doctorate student at Islamic Civilisation Academy, Faculty of Social Sciences and Humanities, Universiti Teknologi Malaysia. Her PhD program is Arabic Language. 